\title{
Profiles of PCBs in Tissues of Marketable Common Carp and Bottom Sediments from Selected Ponds in South and West Bohemia
}

\author{
Z. SVOBODOVÁ ${ }^{1,2}$, V. ŽLÁBEK ${ }^{1,3}$, T. RANDÁK ${ }^{1}$, J. MÁCHOVÁ ${ }^{1}$, J. KOLÁŘOVÁ ${ }^{1}$, \\ J. HAJŠLOVÁ ${ }^{4}$, P. SUCHAN ${ }^{4}$, L. DUŠEK ${ }^{5}$, J. JARKOVSKÝ 5 \\ ${ }^{1}$ University of South Bohemia České Budějovice, Research Institute of Fish Culture and Hydrobiology, \\ Vodňany, Czech Republic \\ 2 Veterinary and Pharmaceutical University, Brno, Czech Republic \\ ${ }^{3}$ University of South Bohemia, Faculty of Agriculture, České Budějovice, Czech Republic \\ ${ }^{4}$ Institute of Chemical Technology, Dept. of Food Chemistry and Analysis, Prague, Czech Republic \\ ${ }^{5}$ Masaryk University, Faculty of Science, Brno, Czech Republic
}

Received August 4, 2003

Accepted December 20, 2003

Abstract

Svobodová Z., V. Žlábek, T., Randák, J. Máchová, J. Kolářová, J. Hajšlová, P. Suchan, L. Dušek, J. Jarkovský: Profiles of PCBs in Tissues of Marketable Common Carp and in Bottom Sediments of Selected Ponds in South and West Bohemia. Acta Vet. Brno 2004, 73: 133-142.

The aim of the study was to evaluate the extent of contamination of six selected ponds in South and West Bohemia by PCBs. For this purpose seven indicator congeners were determined in the tissues of common carp and bottom sediments. The ponds were sampled during autumn periods in the years 1999-2001. Five to seven specimens of three-to four-year-old carp were sampled from every pond. The results demostrated comparable indicative ability of fish tissues and bottom sediments for evaluation of pond load by the monitored PCBs. Considering concentrations of PCBs in fish and bottom sediments, the most contaminated pond was Tovaryš followed by Buzický, Dřemliny, Regent, Bezdrev and Horusický. As regards the distribution of PCBs in fish, the highest values of indicator congeners were found in liver followed by ovaries, muscle and testes. A significant correlation was found between the PCB levels (sum of 7 indicator congeners) and the content of fat in individual tissues of carp $(r=0.83-0.94)$. The pattern of individual indicator congeners in fish was almost the same as that in bottom sediments. The correlation was statistically significant $(\mathrm{r}=0.93)$. This observation is corresponding with slow biotransformation rate of PCBs in fish. The study contributed to the assessment of quality of carp (which is the main representative of marketable fish in the Czech Republic) in terms of its safety as food as well as to evaluation of the pollution of respective aquatic environment.

Cyprinus carpio L., polychlorinated biphenyls, indicator congeners, muscle, liver, gonads, risk assessment

Common carp, with its $87-90 \%$ on total production, is the main freshwater fish species in the Czech Republic both for the local market and for export (Vácha 1998; Vostradovský 2002). Considering requirements for safe food production, attention must be paid to the control of this fish species, as well as to the environment where it is grown. Above all, the effort must be focused on large ponds in which the most of marketable carp is producted. This effort should be further focused on ponds in which municipal waste waters, as well as those from industry were concentrated and treated (or still are concentrated and treated).

Contents of toxic metals and of persistent organic pollutants in muscle of marketable carp from 13 ponds in South- and West Bohemia were monitored during autumn in the years 1991 and 1993 (Svobodová et al. 1999) and later on in 6 selected ponds during 1999-2001. The levels of toxic metals found in tissues of marketable carp and in bottom sediments were reported by Svobodová et al. (2002), persistent organic pollutants (POPs - DDT and its

Address for correspondence:

Prof. MVDr. Zdeňka Svobodová, DrSc.

University of South Bohemia České Budějovice

Research Institute of Fish Culture and Hydrobiology

38925 Vodňany, Czech Republic

Phone: +420383382402

Fax: +420383382396

(1)

http://www_vfu.cz/acta-vet/actavet.htm 
metabolites, $\mathrm{HCH}, \mathrm{HCB}$ and OCS isomers) were subject of matter in a study carried out by Svobodová et al. (2003). The present study focused to polychlorinated biphenyls (PCBs) was aimed at following goals:

- to compare the extent of PCB contamination in six important productive ponds located in South and West Bohemia based upon analyses of tissues of marketable carp and of bottom sediments;

- to determine a relationship between contamination of fish muscle and that of pond environment (bottom sediments);

- to assess the contamination trends on the basis of PCB levels in muscle of carp measured in the selected ponds in 1991-1993 and in 1999-2001;

- to characterize the distribution of 7 indicator congeners of PCBs in the respective tissues of marketable carp;

- to assess the degree of PCB metabolisation in fish according to the patterns of indicator congeners in bottom sediments and those in carp muscle;

- to collect data needed for the assessment of hygienic quality of edible tissues of the main fish species, the carp.

\section{Materials and Methods}

Determination of indicator PCB congeners in tissues of marketable common carp (Cyprinus carpio L.) and in bottom sediments was performed always in autumn during the period 1999 - 2001 during harvest conducted in the following ponds (Fig.1):

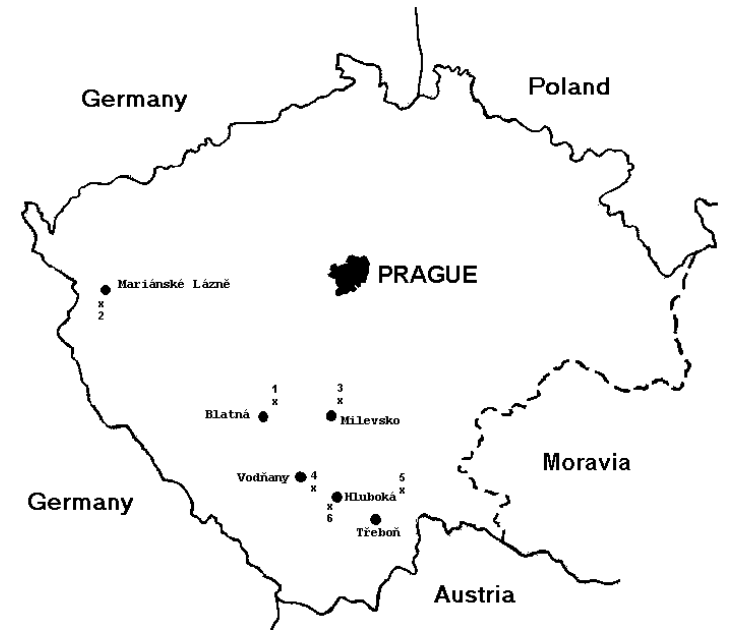

Fig. 1. Map of ponds under study in the region of South and West Bohemia (1-Buzický, 2-Regent, 3-Tovaryš, 4-Dřemliny, 5-Horusický, 6-Bezdrev)

Buzický (55 ha) is a biological pond used for final purification of water from purification plant of municipal wastes from the town of Blatná. It is also filled from Mračovský brook and from Lomnice river, a large drainage area with an intensive agricultural production. Carp ( $85 \mathrm{t}$ harvested) is the main species produced.

Regent ( 52 ha) - a pond situated near by tarmacadam plant for grit. Although it is not in a direct contact with the pond, it is in its gravity field. Carp is the main species produced ( $70 \mathrm{t}$ of marketable fish harvested).

Tovaryš (16 ha) - a pond with intensive agricultural production in its drainage area. Potential sources of industrial pollution in the neighbourhood (air-conditioning works at Milevsko and a tarmacadam plant for grit) are not in a direct contact with the pond but in its drainage area. Carp is the main species produced (10 $\mathrm{t}$ of marketable fish harvested).

Dřemliny (57 ha) - until 1997, it was used for accumulation of municipal and food processing plant waste waters, partly flowing through Čažárka stabilization pond. Later on, waste waters were treated in a sewage treatment plant 
and purification was finished in Čažárka pond. Ninety tons of carp are harvested every autumn, while ten tons are harvested during summer catches.

Horusický (438 ha) - harvest of marketable carp is about 500 t. There is no evidence for any source of pollution.

Bezdrev (434 ha) - carp is the main species produced (harvest of $450 \mathrm{t}$ of marketable carp). The pond accumulates purified waste waters from sewage treatment plants at Zliv, Češňovice and Pištín.

Five to seven specimens of three- to four-year-old carp were sampled from every pond. Immediately after catching, fish were weighed and tissues (muscle, liver, gonads) were sampled. Muscle samples from all ponds under study were sampled and analyzed individually. The same protocol was used for samples of liver, kidney and gonads from the Regent pond. For carp from the other ponds studied, two pooled samples of liver, kidney and gonads were taken and analyzed (one pooled sample of males and one pooled sample of females). Samples were placed in microtene bags, labelled and stored in a freezing box at $-18{ }^{\circ} \mathrm{C}$. Bottom sediments were sampled using a benthos sampler from various part of the pond. A pooled sample was made and stored in a freezing box at $-18^{\circ} \mathrm{C}$ as well.

Tissue samples of marketable carp and samples of bottom sediments were analyzed for the content of 7 indicator PCB congeners (IUPAC NOs. 28, 52, 101, 118, 138, 153 and 180). Homogenized sample was dessicated by anhydrous sodium sulphate and the flowing powder was extracted by hexane - dichloromethane solvent mixture $(1: 1, v / v)$ in a Soxhlet apparatus. Removing of co-extracted lipids from crude extract was accomplished by gel permeation chromatography (GPC) employing BioBeads SX-3 and chloroform as a mobile phase. After solvent evaporation from GPC fraction and dissolving the residue in isooctane, quantification of target analytes was carried out by high resolution two-dimensional gas chromatography (two capillaries operated in parallel) employing two electron capture detectors (HRGC/2xECD). Limits of quantification (LOQ $-\mu \mathrm{gg}^{-1} \mathrm{~kg}^{-1} \mathrm{lipids}$ ) for fish are: PCB $28-0.5$, PCB $52-0.6$, PCB $101-1.0$, PCB $118-0.6$, PCB $138-1.0$, PCB $153-0.6$, PCB $180-0.7$. Limits of quantification (LOQ $\mu \mathrm{g} \cdot \mathrm{kg}^{-1}$ dry matter) for sediment are PCB $28-1.2$, PCB $52-1.8$, PCB $101-2.2$, PCB $118-1.9$, PCB $138-2.4$, PCB $153-1.9$, PCB $180-1.8$.

Results were tested using ANOVA in Statgraphics software and MS-EXCEL 7.0. A non-parametric Spearman correlation was used for comparing the relationship of PCB congeners in fish and in bottom sediments. In order to interprete the results, hygienic limits concerning fish quoted in the Decree of the Ministry of Health of the Czech Republic No. 53/2002 Sb. and ADI values established by the FAO/WHO were used.

\section{Results}

Contents of indicator PCB congeners in tissues of marketable carp from the ponds under study are given in Table 1. Comparison of indicator PCB congeners in muscle (wet weight - w.w.) of marketable carp and in dry matter (dry weight - d.w.) of bottom sediments from ponds under study is shown in Fig. 2. Fig. 3 shows a comparison of the extent of pollution of the respective ponds based upon the content of sum of 7 indicator congeners in carp muscle and in bottom sediments.

The descending order of ponds according to the sum of values of 7 indicator congeners in carp muscle was as followed: Tovaryš, Buzický, Dřemliny, Regent, Bezdrev and Horusický (Fig. 3). Sum of indicator congeners in muscle of carp from Tovaryš pond was significantly higher $(P<0.01)$ when compared to the values in carp from other ponds under study. A significant difference $(P<0.05)$ in the sum of indicator congeners was also found between values in muscle of carp from Buzický and Horusický ponds.

Concerning the patterns of individual indicator PCB congeners, PCB 28 was dominating in muscle of carp from Tovaryš and Regent ponds while congeners with higher content of chlorine $(138,153,180)$ were found to be the major species in other ponds. The levels of individual congeners studied in carp muscle from Tovaryš pond were found significantly exceeding $(P<0.01)$ values of congeners found in carp from all other ponds. There was one exception for values of 138 and 180 congeners in muscle of carp from Buzický pond which were found comparable to the values of fish from Tovaryš pond (Fig. 2).

As regards concentrations of PCBs in bottom sediments, the most contaminated pond was Tovaryš followed by Buzický, Regent, Horusický, Dřemliny and Bezdrev (Fig. 3). The congener 28 was found to be the major one in bottom sediments of Tovaryš and Regent ponds, what was in accordance with its major proportions in muscle of fish from these ponds. 
Table 1

Contents of indicator PCB congeners in tissues ( $\mu \mathrm{g} \cdot \mathrm{kg}^{-1}$ w.w.) of marketable carp from the ponds under study

\begin{tabular}{|c|c|c|c|c|c|c|c|c|c|c|c|c|}
\hline $\begin{array}{l}\text { Pond } \\
\text { Tissue }\end{array}$ & & $n$ & $\begin{array}{c}\text { Body } \\
\text { mass in } \mathrm{g}\end{array}$ & Fat (\%) & PCB 28 & PCB 52 & PCB 101 & PCB 118 & PCB 138 & PCB 153 & PCB 180 & $\Sigma \mathrm{PCB}$ \\
\hline \multicolumn{13}{|l|}{ Buzický } \\
\hline \multirow[t]{2}{*}{ Muscle } & mean & \multirow[t]{2}{*}{5} & 2164 & 7.5 & 1.8 & 2.0 & 4.1 & 1.9 & 10.0 & 6.7 & 4.9 & 31.6 \\
\hline & SD & & 261.2 & 2.58 & 0.44 & 0.27 & 1.17 & 0.61 & 1.78 & 0.92 & 1.14 & 4.92 \\
\hline Liver" & mean & 5 & 2164 & 15.79 & 4.74 & 3.00 & 2.53 & 3.16 & 16.27 & 12.32 & 8.53 & 50.54 \\
\hline Eggs* & female & 3 & 2210 & 8.62 & 1.72 & 1.29 & 4.05 & 2.07 & 7.32 & 4.05 & 5.00 & 25.51 \\
\hline Testes $^{*}$ & male & 2 & 2090 & 1.12 & 0.68 & 0.76 & 0.52 & 0.40 & 2.08 & 1.29 & 1.10 & 6.83 \\
\hline \multicolumn{13}{|l|}{ Regent } \\
\hline \multirow[t]{2}{*}{ Muscle } & mean & \multirow{2}{*}{6} & 3157 & 10.70 & 3.06 & 1.85 & 2.44 & 1.15 & 1.48 & 2.57 & 1.02 & 13.57 \\
\hline & SD & & 408.7 & 4.07 & 1.07 & 0.88 & 2.15 & 0.43 & 0.57 & 1.52 & 0.43 & 5.84 \\
\hline \multirow[t]{2}{*}{ Liver } & mean & \multirow{2}{*}{7} & 3236 & 11.63 & 19.61 & 16.01 & 7.79 & 5.25 & 3.32 & 3.31 & 1.15 & 56.44 \\
\hline & SD & & 427.7 & 6.22 & 11.25 & 10.69 & 4.59 & 4.45 & 2.14 & 2.02 & 0.80 & 31.15 \\
\hline Kidney* & mean & 7 & 3236 & 6.11 & 1.71 & 1.28 & 1.41 & 0.61 & 0.43 & 1.04 & 0.43 & 6.90 \\
\hline \multirow[t]{2}{*}{ Eggs } & mean & \multirow{2}{*}{4} & 3239 & 6.00 & 3.91 & 2.04 & 5.85 & 0.94 & 1.29 & 1.95 & 0.57 & 16.54 \\
\hline & SD & & 587.5 & 3.77 & 4.40 & 1.56 & 9.70 & 0.66 & 1.46 & 1.61 & 0.47 & 19.02 \\
\hline \multirow[t]{2}{*}{ Testes } & mean & \multirow{2}{*}{3} & 3232 & 2.93 & 2.10 & 2.36 & 2.20 & 0.39 & 1.47 & 0.92 & 0.47 & 9.90 \\
\hline & SD & & 176.2 & 1.18 & 0.59 & 0.43 & 1.94 & 0.21 & 1.04 & 0.54 & 0.25 & 4.18 \\
\hline \multicolumn{13}{|l|}{ Dřemliny } \\
\hline \multirow[t]{2}{*}{ Muscle } & mean & \multirow[t]{2}{*}{7} & 1980 & 5.10 & 0.87 & 0.76 & 3.46 & 1.23 & 4.39 & 7.32 & 2.57 & 20.60 \\
\hline & SD & & 276.5 & 1.58 & 0.30 & 0.17 & 0.73 & 0.24 & 1.37 & 1.60 & 0.54 & 4.41 \\
\hline \multirow[t]{2}{*}{ Liver* } & female & 3 & 1775 & 4.09 & 0.61 & 0.50 & 3.35 & 0.86 & 4.74 & 5.54 & 1.89 & 17.49 \\
\hline & male & 4 & 2134 & 3.11 & 0.52 & 0.50 & 2.40 & 0.83 & 3.19 & 5.00 & 1.80 & 14.24 \\
\hline Eggs" & female & 3 & 1775 & 4.15 & 0.75 & 0.55 & 1.97 & 0.69 & 2.68 & 3.54 & 1.33 & 11.51 \\
\hline Testes* & male & 4 & 2134 & 0.67 & 0.23 & 0.18 & 0.56 & 0.23 & 0.94 & 1.16 & 0.38 & 3.69 \\
\hline \multicolumn{13}{|l|}{ Tovaryš } \\
\hline \multirow[t]{2}{*}{ Muscle } & mean & \multirow{2}{*}{7} & 1689 & 4.26 & 34.18 & 17.77 & 11.18 & 8.11 & 8.62 & 13.24 & 5.76 & 98.85 \\
\hline & SD & & 181.1 & 1.47 & 10.99 & 5.75 & 3.74 & 2.64 & 2.77 & 4.52 & 1.95 & 32.17 \\
\hline \multirow[t]{2}{*}{ Liver } & female & 4 & 1673 & 9.73 & 83.91 & 39.94 & 28.30 & 18.51 & 22.58 & 31.29 & 13.24 & 237.74 \\
\hline & male & 3 & 1710 & 13.34 & 113.84 & 58.01 & 37.93 & 28.16 & 29.39 & 46.20 & 20.68 & 334.22 \\
\hline Testes" & male & 3 & 1710 & 2.37 & 20.99 & 9.96 & 7.78 & 4.37 & 5.78 & 7.23 & 2.90 & 59.00 \\
\hline \multicolumn{13}{|l|}{ Bezdrev } \\
\hline Muscle & mean & 7 & 2469 & 3.11 & 0.28 & 0.29 & 1.76 & 0.53 & 2.95 & 4.29 & 1.57 & 11.68 \\
\hline & SD & & 204.6 & 1.58 & 0.07 & 0.07 & 0.66 & 0.18 & 1.10 & 1.50 & 0.53 & 4.02 \\
\hline Liver* & female & 5 & 2522 & 6.50 & 0.87 & 0.64 & 3.30 & 1.16 & 6.07 & 9.44 & 3.93 & 25.40 \\
\hline & male & 2 & 2338 & 3.76 & 1.06 & 0.48 & 2.98 & 0.84 & 5.37 & 7.15 & 2.47 & 20.34 \\
\hline Eggs" & female & 2 & 2688 & 5.81 & 0.59 & 0.52 & 2.58 & 0.98 & 4.85 & 7.76 & 2.58 & 19.87 \\
\hline Testes" & male & 2 & 2338 & 1.39 & 0.19 & 0.17 & 0.93 & 0.29 & 1.52 & 2.15 & 0.76 & 6.01 \\
\hline Horusick & & & & & & & & & & & & \\
\hline Muscle & mean & 7 & 2190 & 4.39 & 0.23 & 0.28 & 0.65 & 0.26 & 1.19 & 1.39 & 0.52 & 4.52 \\
\hline & $\mathrm{SD}$ & & 166.8 & 1.68 & 0.07 & 0.10 & 0.15 & 0.06 & 0.21 & 0.29 & 0.11 & 0.83 \\
\hline Liver* & female & 2 & 2355 & 9.92 & 0.40 & 0.65 & 1.67 & 0.74 & 3.82 & 4.51 & 1.79 & 13.60 \\
\hline & male & 5 & 2124 & 13.31 & 0.47 & 0.73 & 1.83 & 0.81 & 4.35 & 4.58 & 1.66 & 14.43 \\
\hline Eggs" & female & 2 & 2355 & 9.90 & 0.64 & 0.47 & 1.55 & 0.75 & 4.00 & 4.36 & 1.77 & 13.54 \\
\hline Testes" & male & 5 & 2124 & 1.37 & 0.21 & 0.14 & 0.31 & 0.11 & 0.56 & 0.65 & 0.20 & 2.19 \\
\hline
\end{tabular}

Note* - Pooled sample

Congeners with higher chlorine content were found to be dominant in Buzický and Horusický ponds. In case of Dřemliny and Bezdrev ponds, most of the congeners studied were below the limit of detection of the method used (Fig. 2).

The distribution of PCBs in tissues was statistically evaluated in marketable carp from Regent pond. The highest values of sum of 7 indicator congeners were found in liver followed by ovaries, muscle and testes. There was a significant difference $(P<0.05)$ between the sum of indicator congeners in liver and in other tissues. The same difference was also found for 

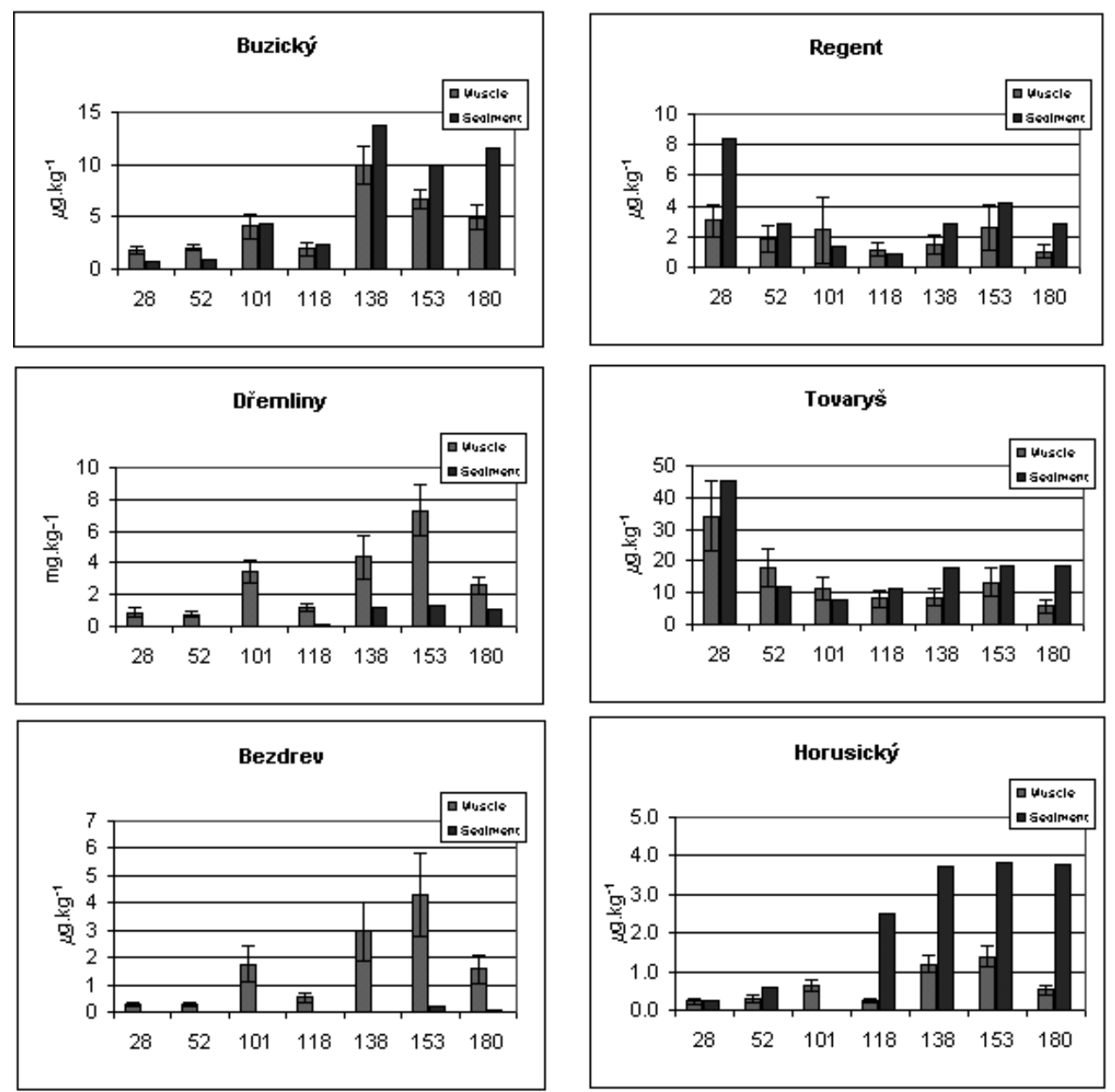

Fig 2. Comparison of the contents of individual indicator PCB congeners in carp muscle $\left(\mu \mathrm{g} \cdot \mathrm{kg}^{-1} \mathrm{w} . \mathrm{w}\right.$.) and dry matter of bottom sediments $\left(\mu \mathrm{g} \cdot \mathrm{kg}^{-1} \mathrm{~d} . \mathrm{w}\right.$.) from the ponds under study

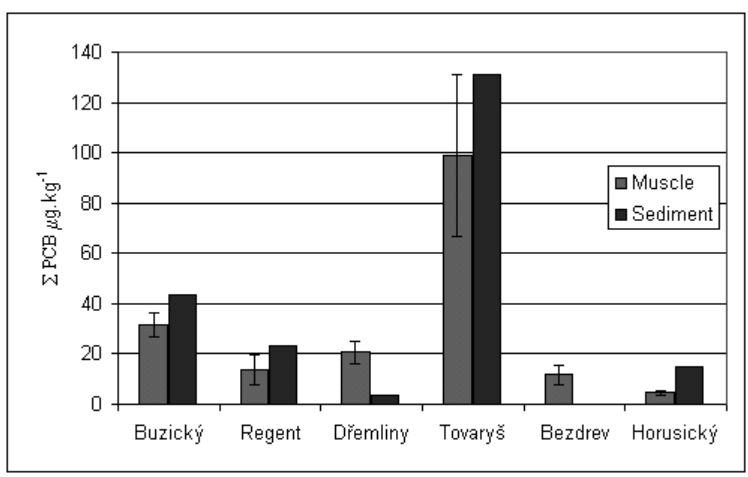

Fig. 3 . Comparison of the contents of sum of PCBs in carp muscle ( $\left.\mu \mathrm{g} \cdot \mathrm{kg}^{-1} \mathrm{w} . \mathrm{w}.\right)$ and dry matter of bottom sediments $\left(\mu \mathrm{g} \cdot \mathrm{kg}^{-1}\right.$ d.w.) 
congeners 28 and 52. In these congeners, the difference between the content in liver and in muscle was significant $(P<0.01)$. The sequence of tissues according to the values of congeners $101,118,138,153$ and 180 was the same as that according to the sum of indicator congeners. Differences in values among individual tissues were insignificant. Similarly, the sequence of tissues of marketable carp from the majority of the ponds according to the sum of 7 indicator congeners was the same as for the Regent pond. Substantial differences in the content of PCBs in ovaries and in testes were in accordance with differing content of fat which was up to several-fold higher in ovaries than in testes. This fact referred to the proven high relationship of PCB contents on the contents of fat in tissues of fish from the same pond (for the Regent pond $r=0.68$, for the other ponds $r=0.83-0.94$ ).

\section{Discussion}

To evaluate the extent of pollution, two components of aquatic environment were examined for PCB levels: biota were represented by fish and abiotic matrix were represented by sediments.

The latter are used in numerous studies as bioindicators of the loading. Marketable carp was used as indicator, as it was grown in the ponds under study for one year (in annual cycle of Buzický, Tovaryš and Dřemliny ponds), or for two years (in biennial cycle of Regent, Horusický and Bezdrev ponds).

In agreement with our anticipation, significantly higher pollution was proven for Tovaryš and Buzický ponds upon results of analyses of both the fish and bottom sediments.

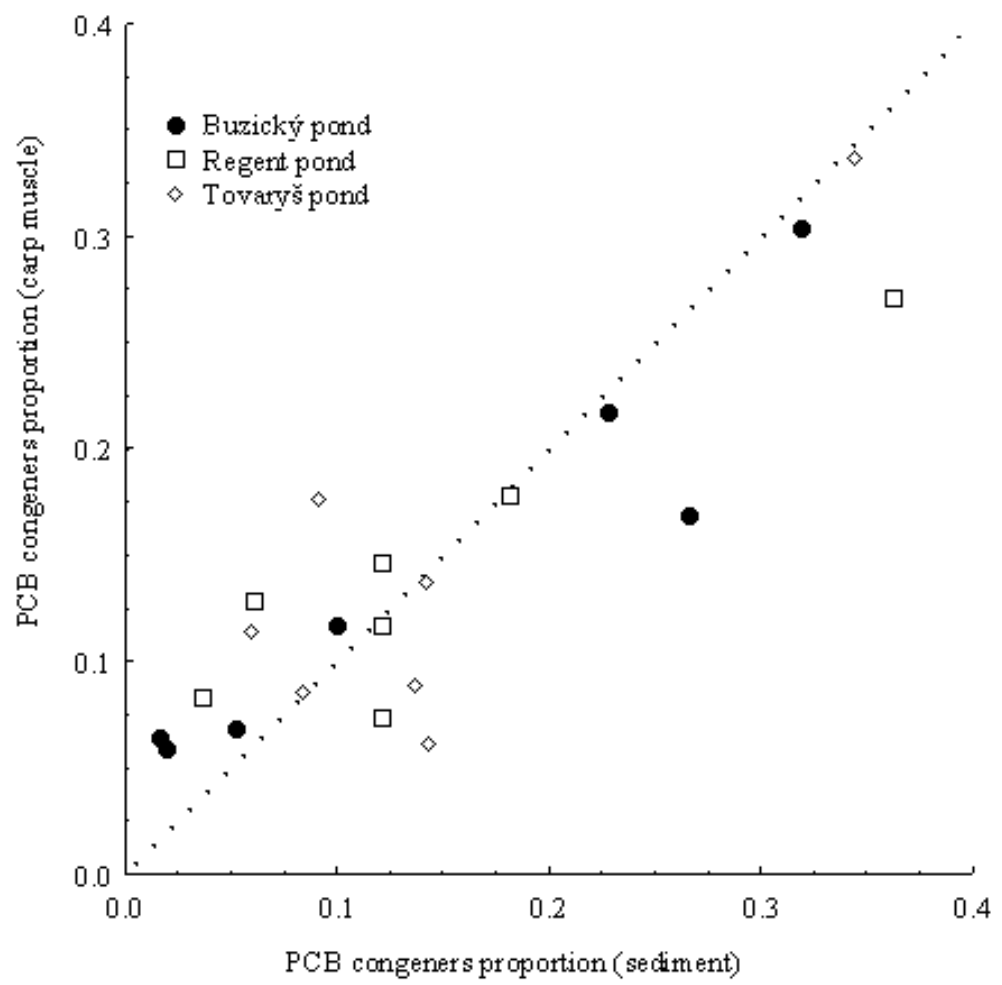

Fig. 4. Correlation between the PCB congeners proportions (relative amounts) in bottom sediments and carp muscle 
The Buzický pond (Blatná town) retains municipal waste waters with a high ratio of industrial wastes while in the drainage area of Tovaryš pond, there are important industrial plants and a tarmacadam plant for grit. High loading of the Tovaryš pond with $\mathrm{PCBs}$ and with polycyclic aromatic hydrocarbons (PAHs) was also reported by Machala et al. (1997) who measured biochemical markers of contamination in hepatic microsomes of carp (EROD, PROD).

Results obtained from examination of Buzický, Regent and Tovaryš ponds were used for comparison of proportions of individual indicator congeners of PCBs in bottom sediments and in carp muscle. In these three ponds the values of all congeners in bottom sediments and in fish were found to be above the limit of detection of the method used. As shown in Fig. 2, the pattern of individual indicator congeners was nearly the same in bottom sediments and in fish. In a general overview, this phenomenon can be observed in Fig. 4, where the proportions (relative amounts) of individual indicator congeners approximate the $\mathrm{X}=\mathrm{Y}$ line. Spearman's correlation of the proportion of congeners in sediments and in fish was determined as a subsidiary index. The correlation was statistically significant with value of 0.93 . This conclusion is corresponding to the previous data on a very slow process of PCB biotransformation in fish (Sijm et al. 1992), according a similar distribution of PCB congeners is recognized in fish and in the surrounding abiotic environment. In this context fish is very good bioindicator of pollution situation. Substantially more intensive biotransfomation of some PCBs, especially lower chlorinated congeners including indicator PCBs 28 and 52 occurs in warm blooded vertebrates (Boer and Brinkman 1994; Oost et al. 2003; Schmidt et al. 1990). Variations from identical proportions of individual congeners in fish and in the surrounding abiotic environment might be caused by possible spatial heterogeneity of sediments and variability of biological samples.

Comparison of mean data of the content of indicator congeners of PCBs in muscle of marketable carp registered in 1992-1993 (Svobodová et al. 1999) and in 1999-2000 in the ponds studied is shown in Fig. 5. Unfortunately, only analyses of pooled samples $(n=5)$ in 1992-1993 were carried out, and the statistical assessment of data was impossible. Despite of that, the developmental trends could be indicated. Basically, there was no change in PCB loading of Buzický and Horusický ponds during the compared periods. In Regent pond, there was approximately $27 \%$ decrease of PCB contamination during 1992 - 1999. In contrary, increased values of the sum of 7 indicator congeners in muscle of marketable fish were found in the remaining three ponds. The increases were 47, 90 and even 132\% in Tovaryš, Dřemliny and Bezdrev ponds, respectively. These findings might seem to be inconsistent with the fact that PCBs use was banned in the 1980s. However, disclosure of old loadings (by shift of bottom sediments) and/or insufficient control of contaminated soil depots might be the main sources of PCB contamination in these cases. This status might be anticipated in case of Bezdrev pond. These hypotheses confirm present data reporting that $5 \%$ of the total production of PCBs was harmlessly erradicated, $30 \%$ persist in the environment and in food webs and $65 \%$ of the total production was deposited in various dumpings or storage yards (Kocan et al. 2002).

Further comparison and interpretation of the results observed in this study was limited due to the lack of relevant literature data. Results of PCBs contents in tissues of carp grown in ponds could not be compared to those from open waters. These waters are stocked with carp grown in ponds up to $2-4$ years of age and thus they cannot be considered indicator fish for contamination. Similarly, there are very limited data from other countries on the content of PCBs in tissues of carp. Pond production of marketable carp is mostly specific for Central- and Eastern Europe (Vácha 1998). 

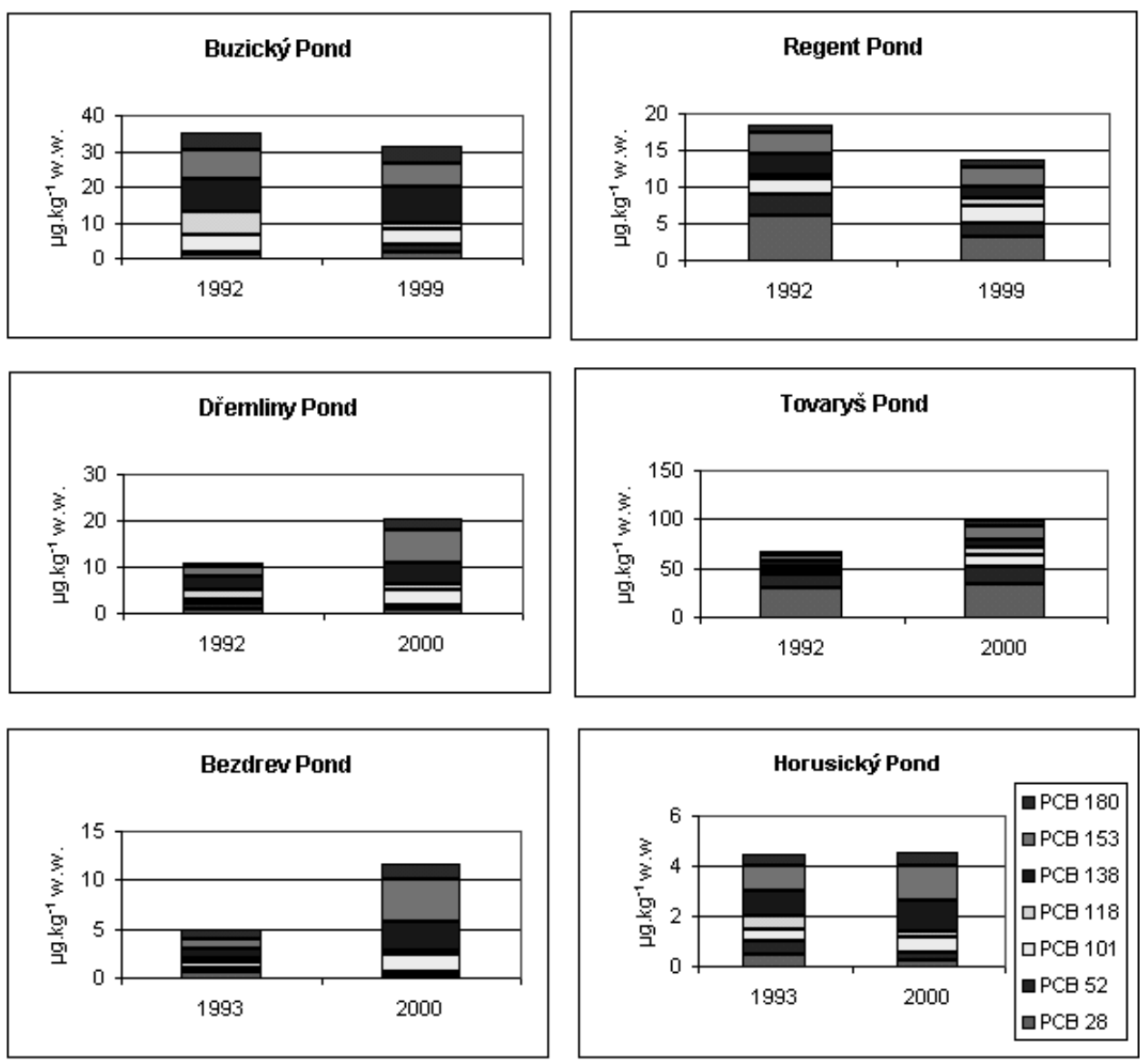

Fig. 5. Comparison of the contents of PCB congeners in carp muscle in the years $1992-2000$

Polychlorinated biphenyls are lipophilic substances and their accumulation is significantly affected by the content of fat in tissues (Niimi and Oliver 1989; Parkerton et al. 1991; Hajšlová et al. 1997; Ciereszko 2001). This fact was exemplified on the following 5 ponds - Bezdrev, Buzický, Dřemliny, Horusický and Tovaryš, where a high correlation was found between the content of PCBs (sum of 7 indicator congeners) and content of fat in individual tissues of carp ofidentical origin $(r=0.83-0.94)$. A simple analysis of the difference showed that contamination of fat extracted from muscle, liver and gonads of fish from the same environment (the same pond) was comparable and did not differ significantly between these tissues (Fig. 6).

Concerning the quality assessment of marketable carp from the point of view of PCB content it could be noted that the values found for the content of 7 indicator congeners did not exceed the value given in Decree No. 53, Ministry of Health of the Czech Republic, issued in 2002. The maximum residue limits for the sum of 7 indicator congeners in edible parts of the fish are $2 \mathrm{mg} \cdot \mathrm{kg}^{-1}$ (w.w.).

The ADI value determined by WHO in 2001 is $5 \mu \mathrm{g} \cdot \mathrm{kg}^{-1} \cdot \mathrm{day}^{-1}$ of the sum of 7 indicator congeners of PCBs. Tovaryš pond with the highest values of content of this pollutant, was selected for assessment of hygienic risk. To reach the ADI, a human of $70 \mathrm{~kg}$ body weight 
would have to consume $3.5 \mathrm{~kg}$ of carp flesh daily. Mean annual consumption of freshwater fish in the Czech Republic is $1 \mathrm{~kg}$ per capita (Berka 1998), i.e. $2.74 \mathrm{~g}$ per capita daily. Consuming fish from this most contaminated pond, the dietary exposure would not exceed $0.1 \%$ of the ADI value. Also risk assessment recommended by Kann an et al. (1998) shows a negligible hazard of dietary exposure to the PCBs under study.
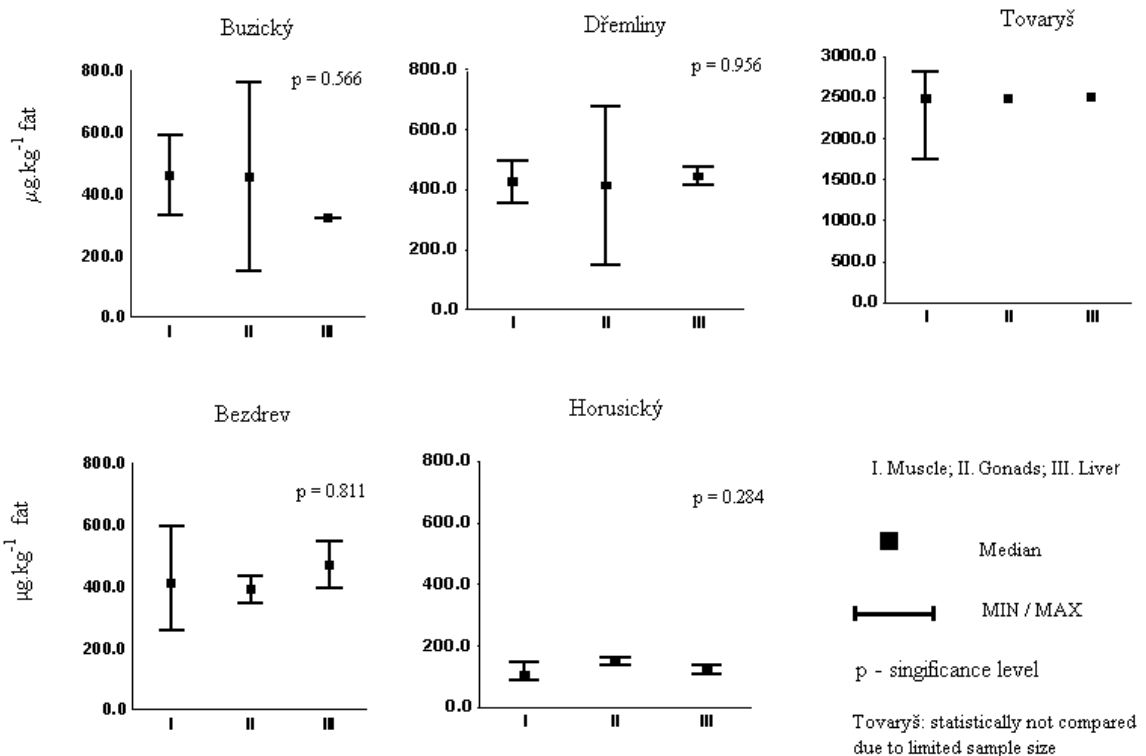

Fig. 6. Comparison of the PCB contents (sum of 7 indicator congeners) in fat of muscle, gonads and liver of carp from the ponds under study

\section{Obsah polychlorovaných bifenylů v tkáních tržních kaprů obecných a v sedimentech dna vybraných rybníků jižních a západních Čech}

Cílem práce bylo posoudit stav vybraných rybníků jižních a západních Čech z hlediska obsahu polychlorovaných bifenylů $\mathrm{PCB} v \mathrm{v}$ tkáních kaprů a $\mathrm{v}$ sedimentech dna. V podzimním období 1999 - 2001 byly vyšetřovány rybníky Buzický, Regent, Tovaryš, Dřemliny, Horusický a Bezdrev. Z každého rybníka bylo odebráno 5-7 kusů tržních kaprů, analyzovány byly vzorky svaloviny, jater a gonád. V tkáních ryb a v sedimentu dna byl sledován obsah 7 indikátorových kongenerů PCB. Výsledky analýz ryb a sedimentů dna určily následující sestupné pořadí rybníků z hlediska jejich zátěže PCB: Tovaryš, Buzický, Dřemliny, Regent, Bezdrev, Horusický.

Z výsledkủ hodnocení distribuce $\mathrm{PCB}$ v rybách vyplynulo ve většině případů následující pořadí tkání podle výše obsahu sledovaných PCB: játra, jikry, svalovina, mlíčí. Uvedené pořadí je ovlivněno rozdílným obsahem tuku v jednotlivých tkáních (statisticky prokázána vysoká korelace mezi obsahem tuku a PCB v tkáních ryb stejného původu, $r=0,83-0,99$ ). Dále bylo prokázáno, že poměry jednotlivých indikátorových kongenerů zjištěných $\mathrm{v}$ sedimentech dna a $\mathrm{v}$ rybách jsou prakticky shodné $(\mathrm{r}=0,93)$. Toto zjištění potvrzuje předpoklad, že PCB přijaté rybami podléhají minimální metabolizaci. Předložená práce je příspěvkem ke zhodnocení vlivu prostředí na hygienickou kvalitu kaprů - hlavních zástupců tržních ryb na území ČR. Vedle toho práce upozorňuje na potenciální riziko zvyšování zátěže rybničního prostředí polychlorovanými bifenyly $\mathrm{v}$ důsledku obnažování starých zátěží nebo nedostatečného zabezpečení skládek s vytěženou kontaminovanou zeminou. 


\section{Acknowledgements}

This research was supported by the Ministry of Education, Youth and Sports of the Czech Republic (MSM Project No. 126100003) and Ministry of Agriculture of the Czech Republic (Department of Food Production).

\section{References}

BERKA, R 1998: Sladkovodní ryby - co s nimi dál. Výživa a potraviny 53: 106-107

de BOER, J. BRINKMAN, UATh 1994: The use of fish as biomonitors for the determination of contamination of the aquatic environment by persistent organochlorine compounds. Trends Anal Chem 13: 397-404

CIERESZKO, W 2001: Accumulation dynamics of PCBs in selected organs and tissues of carp (Cyprinus carpio L.). Acta Ichthyol Piscat 31: 105-117

HAJŠLOVÁ, J, SCHOULA, R, KOCOUREK, V, HOLADOVÁ, K, POUSTKA, J, KOHOUTKOVÁ, J, SVOBODOVÁ, Z 1997: Polychlorinated biphenils and other persistent chlorinated contaminants in fish as indicators of pollution of aquatic ecosystem in Czech Republic. Toxicol Environ Chem 59: 279-291

KANNAN, K, SMITH, RG, LEE, RF, WINDOM, HL, HEITMULLER, PT, MACAULEY, JM, SUMMERS, JK 1998: Distribution of total mercury and methylmercury in water, sediment and fish from south Florida estuaries. Arch Environ Contam Toxicol 34: 109-118

KOCAN, A, PETRIK, J, JURSA, S, DROBNÁ, B, CHOVANCOVÁ, J, SUCHÁNEK, P 2002: PCB production in Slovakia and environmental contamination. Book of Abstracts "The Second PCB Workshop", Masaryk University Brno, p. 10

MACHALA, M, NEZVEDA, K, PETŘIVALSKÝ, M, JAROŠOVÁ, A, PIAČKA, V, SVOBODOVÁ, Z 1997: Monooxygenase activities in carp as biochemical markers of pollution by polycyclic and polyhalogenated aromatic hydrocarbons: choise of substrates and effects of temperature, gender and capture stress. Aquatic Toxicology 37: 113-123

NIIMI, J, OLIVER, BG 1989: Distribution of polychlorinated biphenyl congeners and other halocarborns in whole fish and muscle from Lake Ontario salmonids. Environ Sci Technol 23: 83-88

van der OOST, R, BEYER, J, VERMEULEN, NPE 2003: Fish bioaccumulation and biomarkers in environmental risk assessment: a review. Environ Toxicol Pharmac 13: 57-149

PARKERTON, TF, CONNOLLY, JP, THOMANN, RV, UCHRIN, CG 1991: Do aquatic effects or human health and points govern the development of sediment-quality criteria for nonionic organic chemicals? Int Toxicol Chem 12: 507-523

SCHMIDT, CJ, ZAJICEK, J, PETERMAN, PH 1990: National contaminant biomonitoring program: Residues of organochlorine chemicals in U.S. fresh-water fish: 1976-1984. Arch Environ Contam Toxicol 19: 748-781

SIJM, DTHM, SEINEN, W, OPPERHUIZEN, A 1992: Life - cycle biomagnification study. Environ Sci Technol 26: 2163 - 2174

SVOBODOVÁ, Z, RANDÁK, T, VYKUSOVÁ, B 1999: Results of monitoring the contents of metals and of selected organic pollutants in muscles of carp from ponds of South and West Bohemia. Bull VÚRH Vodňany 35: 194-213

SVOBODOVÁ, Z, ŽLÁBEK, V, ČELECHOVSKÁ, O, RANDÁK, T, MÁCHOVÁ, J, KOLÁŘOVÁ, J, JANOUŠKOVÁ, D, 2002: Content of metals in tissues of marketable common carp and in bottom sediments of selected ponds of South and West Bohemia. Czech J Anim Sci 47: 339-350

SVOBODOVÁ, Z, ŽLÁBEK, V, RANDÁK, T, MÁCHOVÁ, J, KOLÁŘOVÁ, J, HAJŠLOVÁ, J, SUCHAN, P 2003: Profiles of POPs in marketable common carp tissues and bottom sediments from selected ponds of South and West Bohemia. Acta Vet Brno 72: 295-309

VÁCHA, F 1998: Information on Czech Republic fisheries. Eds. Hickley, P, Tompkins, H Fishing New Books, Blackwell Science: $48-57$

VOSTRADOVSKÝ, J 2002: Den českého produkčního rybářství. Rybářství 105: 40-41 